\title{
Technology, Knowledge Spillovers, and Changes in Employment Structure: Evidence from Six OECD Countires
}

Citation for published version (APA):

Hollanders, H. J. G. M., \& ter Weel, B. J. (2002). Technology, Knowledge Spillovers, and Changes in Employment Structure: Evidence from Six OECD Countires. Labour Economics, 9((5)), 579-599. https://doi.org/10.1016/S0927-5371(02)00056-8

Document status and date:

Published: 01/01/2002

DOI:

10.1016/S0927-5371(02)00056-8

Document Version:

Publisher's PDF, also known as Version of record

Please check the document version of this publication:

- A submitted manuscript is the version of the article upon submission and before peer-review. There can be important differences between the submitted version and the official published version of record.

People interested in the research are advised to contact the author for the final version of the publication, or visit the DOI to the publisher's website.

- The final author version and the galley proof are versions of the publication after peer review.

- The final published version features the final layout of the paper including the volume, issue and page numbers.

Link to publication

\footnotetext{
General rights rights.

- You may freely distribute the URL identifying the publication in the public portal. please follow below link for the End User Agreement:

www.umlib.nl/taverne-license

Take down policy

If you believe that this document breaches copyright please contact us at:

repository@maastrichtuniversity.nl

providing details and we will investigate your claim.
}

Copyright and moral rights for the publications made accessible in the public portal are retained by the authors and/or other copyright owners and it is a condition of accessing publications that users recognise and abide by the legal requirements associated with these

- Users may download and print one copy of any publication from the public portal for the purpose of private study or research.

- You may not further distribute the material or use it for any profit-making activity or commercial gain

If the publication is distributed under the terms of Article $25 \mathrm{fa}$ of the Dutch Copyright Act, indicated by the "Taverne" license above, 


\title{
Technology, knowledge spillovers and changes in employment structure: evidence from six OECD countries
}

\author{
Hugo Hollanders ${ }^{1}$, Bas ter Weel ${ }^{*}$ \\ Maastricht Economic Research Institute on Innovation and Technology, Maastricht University, P.O. Box 616, \\ 6200 MD Maastricht, Netherlands
}

Received 1 February 2001; received in revised form 1 October 2001; accepted 1 March 2002

\begin{abstract}
This paper investigates and compares changes in the employment structure in manufacturing in Finland, France, Germany, Japan, the United Kingdom and the United States in the period 19751995. Using data on employment by skill level and type and several measures of an industry's technological advancement, we find a positive relationship between skill upgrading and R\&D intensity. Since technology has some characteristics of a public good, it is important to include into the analysis spillovers explaining the changes in employment structure. Including knowledge spillovers lowers the estimates for R\&D intensity substantially and shows a significant impact of knowledge spillovers on skill upgrading. In addition, splitting the sample into high-tech and low-tech industries reveals that the joint impact of spillovers in explaining skill upgrading in low-tech industries is more important than the impact of R\&D itself. Furthermore, using three different definitions of skill, we find different point estimates for the impact of technology variables on skill upgrading. The results reveal that both the development of technology (through R\&D) and its application (through spillovers) is skilled-biased, and not just the development as is often assumed in previous work.
\end{abstract}

(C) 2002 Elsevier Science B.V. All rights reserved.

JEL classification: $\mathrm{J} 31 ; \mathrm{O} 30$

Keywords: Skill-biased technological change; Wage differentials by skill; Knowledge spillovers

${ }^{*}$ Corresponding author. Tel.: +31-43-3883873.

E-mail addresses: h.hollanders@merit.unimaas.nl (H. Hollanders), b.terweel@merit.unimaas.nl (B. ter Weel).

${ }^{1}$ Tel.: +31-43-3883873. 


\section{Introduction}

Wage inequality and educational wage differentials have increased substantially over the past two decades. Particularly in the United Kingdom and the United States, the widening of the wage structure has been pronounced (e.g. Bound and Johnson, 1992; Juhn et al., 1993; Machin, 1996). At the same time, the employment structure within many sectors of industry has also been changing in favour of skilled workers (e.g. Berman et al., 1994; Doms et al., 1997; Machin and Van Reenen, 1998). These changes in the structure of wages and employment have coincided with surges in technological change such as the computerization of the workplace (e.g. Autor et al., 1998; Borghans and ter Weel, 2001) and capital deepening (e.g. Murphy and Welch, 1992; Bartel and Sicherman, 1999). ${ }^{2}$ Not surprisingly, many studies have focussed on a causal relationship between the changing structure of wages and employment and the increase in the growth rate of the relative demand for more skilled workers driven by technological change.

The consensus in the debate is that changes in technology over the past two decades are responsible for the changes in the structure of wages and employment. Two pieces of evidence are often cited to explain these patterns of skill-biased technological change. First, the relative employment of more skilled workers has increased rapidly despite their higher wages, which is consistent with an outward shift of the production possibility frontier. Second, the employment of more skilled workers is positively correlated with capital intensity, R\&D intensity and the introduction of new technologies. Most of the econometric literature has focussed on the United States. For example, Bound and Johnson (1992), Katz and Murphy (1992), Murphy and Welch (1992), Juhn et al. (1993), Berman et al. (1994), Doms et al. (1997), Autor et al. (1998), Goldin and Katz (1998), Adams (1999), Bartel and Sicherman (1999), Krusell et al. (2000) and Gould et al. (2001) provide strong evidence that the labour-market position of more-skilled workers has improved substantially. More recent work also focussed on cross-country comparisons. Studies aiming to compare the structure of wages and employment between countries are the collected papers in the conference volume of Freeman and Katz (1995). ${ }^{3}$

From the literature investigating the effects of technological change on productivity, it is well known that not only technological change itself is important, but that there are significant effects of spillovers to explain productivity growth. ${ }^{4}$ Since technology has many features of being a public good (widely applicable and hard to fully appropriate) and since the literature on endogenous growth theory (e.g. Romer, 1990) has stressed the importance of this feature, it might be important to investigate the role of spillovers in the

2 Bartel and Sicherman (1999) use the following five measures to investigate the impact of technology on skilled labour demand: (i) total factor productivity; (ii) the ratio of investment in computers to total investments; (iii) the ratio of R\&D funds to net sales; (iv) the number of patents used in a particular sector; and (v) the ratio of scientific and engineering employment to total employment. There findings suggest a strong positive correlation between these five measures of technological change and changes in wage and employment structures in favour of skilled workers in the United States.

3 Chennells and Van Reenen (1999) and Acemoglu (2002) provide overviews of this literature.

4 See, e.g. Jaffe (1986), Verspagen (1997a) and Soete and ter Weel (1999). Griliches (1992) provides an elaborate overview of the literature searching for technology spillovers in general. 
debate on skill-biased technological change. When there is scope for spillovers and when there exists a complementary relationship between technology and more-skilled workers, not only the creation of technology but also its spread and utilization by means of spillovers is an important factor to account for. Among the several sources of technological change that have been proposed, $\mathrm{R} \& \mathrm{D}$ is among the most popular measures. The reason to choose $\mathrm{R} \& \mathrm{D}$ is that it is a directly observable indicator, which can be relatively easy correlated with the degree of skill upgrading and for which data are readily available. However, "the level of knowledge in any one sector or industry not only is derived from own research and development investments but also is affected by the knowledge borrowed or stolen from other sectors or industries" (Griliches, 1979, p. 100). This means that the productivity of one sector or industry will depend not only on its own R\&D expenditures but also on the effort put in R\&D in other sectors or industries. Most studies neglect to a large extent such spillovers from one industry to another. ${ }^{5}$

A second issue is that most studies adopting an international perspective use the change in the share of nonproduction workers as an indication for skill upgrading. Although the distinction between production and nonproduction workers is probably correlated with the share of educated workers across industries both in levels and cross section, this is a rather crude measure to define "unskilled" and "skilled" labour, because it underestimates the concept of skill-biased technological change in two respects. First, not all production workers are unskilled, e.g. many skilled blue-collar workers, like some engineers, are classified as production workers. Second, not all nonproduction workers are skilled, e.g. clerks, service workers and shop and market sales workers are relatively unskilled whitecollar workers. Here we use a more comprehensive distinction made on the basis of four types of labour: white-collar and blue-collar high-skilled and low-skilled workers. This will enable us not only to make a distinction between blue and white-collar workers, but also between more and less skilled workers.

The contribution of this paper is that we adopt a more elaborate method to measure the importance of spillovers to explain skill upgrading and use more detailed information on the definition of skills to analyse changes in the employment shares of skilled workers. Besides using R\&D and a wide spectrum of bilateral trade flows, this method also uses patent citations to examine the flows of "knowledge" between 22 manufacturing industries in six OECD countries (Finland, France, Germany, Japan, the United Kingdom and the United States) from 1975 to 1995. The results of this analysis, first suggested by Putnam and Evenson (1994) and Verspagen (1997b), can be summarized as follows. We find a positive relationship between skill upgrading and technological change measured by an industry's R\&D intensity. Including knowledge spillovers lowers the estimates for R\&D intensity substantially and shows a significant impact of knowledge spillovers on skill upgrading. In addition, splitting the sample into high-tech and low-tech industries

\footnotetext{
5 Machin and Van Reenen (1998) only consider a brief section based on a spillover study by Coe and Helpman (1995), which suggests that spillovers may play an important role in explaining skill-biased technological change, because not only technology-creating but also technology-absorbing manufacturing industries may be affected in some way by innovations and new technologies.
} 
reveals that the impact of spillovers in explaining skill upgrading in low-tech industries is more important than the impact of R\&D itself. These results point at the importance of spillovers in explaining changing employment patterns resulting from technological change. In addition, the results reveal that both the development and application and spread of technology (measured by spillovers) is skill biased and not only the development, as often assumed in previous work.

The results regarding the more detailed information on skills are mixed. From a theoretical point of view, it seems obvious to split the sample of skilled and unskilled workers using human capital factors as distinctive features. A priori, it is important to make this distinction because our results indicate that white-collar high-skilled workers have profited most from recent technological change, a result already established in many studies using data on individual workers but never shown on an international manufacturing sector level. However, while the coefficients using different measures of skill differ, the differences are not statistically significant.

The remainder of this paper is organized as follows. First the data are described. Second, the econometric specification is presented. Third, the estimation results are presented. We end with some concluding remarks.

\section{Data description}

We draw on a number of data sources to construct the industry-level panel data we use in our empirical approach. First, we use the Structural Analysis (STAN) database (OECD, 1998b) for data on investment and value added for 22 industries in all six countries. The STAN database includes estimates compatible with national accounts for measures such as production, value added, gross fixed capital formation, employment, labour compensation, exports and imports on an industry level for 22 OECD countries. ${ }^{6}$

Second, we use the Analytical Business Enterprise Research and Development (ANBERD) database (OECD, 1999) for R\&D expenditures. The ANBERD database has been developed to provide a consistent database that overcomes the problems of international comparability and breaks in the time series of the official business enterprise R\&D as provided by the OECD member countries. ANBERD includes data on R\&D expenditures on an industry level for 15 OECD countries. Combining the data on value added from STAN and the R\&D expenditures from ANBERD, we define high-, medium-

\footnotetext{
${ }^{6}$ The 22 industries included in our analysis (ISIC Revision 2 code in parentheses) are: Food, beverages and tobacco (31), Textiles, apparel and leather (32), Wood products and furniture (33), Paper, paper products and printing (34), Other chemicals $(351+352-3522)$, Pharmaceuticals (3522), Refined oil and related products $(353+354)$, Rubber and plastic products $(355+356)$, Glass, stone and clay (36), Ferrous metals (371), Nonferrous metals (372), Metal products (381), Nonelectrical machinery (382-3825), Office and computing equipment (3825), Electrical machinery (383-3832), Radio, TV and communication equipment (3832), Shipbuilding (3841), Automobiles (3843), Aerospace (3845), Other transport (384-3841-3843-3845), Instruments (385) and Other manufacturing (39).
} 
Table 1

R\&D intensity in manufacturing, 1975-1995

\begin{tabular}{|c|c|c|c|c|c|}
\hline & 1975 & 1980 & 1985 & 1990 & 1995 \\
\hline Finland & 0.033 & 0.037 & 0.048 & 0.055 & 0.057 \\
\hline High-tech industries & 0.169 & 0.172 & 0.183 & 0.195 & 0.200 \\
\hline Medium-tech industries & 0.044 & 0.045 & 0.049 & 0.051 & 0.052 \\
\hline Low-tech industries & 0.015 & 0.015 & 0.016 & 0.016 & 0.015 \\
\hline France & 0.051 & 0.057 & 0.069 & 0.069 & 0.070 \\
\hline High-tech industries & 0.211 & 0.210 & 0.226 & 0.225 & 0.225 \\
\hline Medium-tech industries & 0.054 & 0.061 & 0.073 & 0.071 & 0.072 \\
\hline Low-tech industries & 0.010 & 0.010 & 0.012 & 0.011 & 0.012 \\
\hline Germany & 0.045 & 0.055 & 0.063 & 0.067 & 0.071 \\
\hline High-tech industries & 0.142 & 0.141 & 0.143 & 0.164 & 0.166 \\
\hline Medium-tech industries & 0.066 & 0.080 & 0.084 & 0.084 & 0.085 \\
\hline Low-tech industries & 0.004 & 0.009 & 0.013 & 0.011 & 0.011 \\
\hline Japan & 0.052 & 0.048 & 0.064 & 0.077 & 0.072 \\
\hline High-tech industries & 0.135 & 0.113 & 0.134 & 0.156 & 0.150 \\
\hline Medium-tech industries & 0.071 & 0.059 & 0.070 & 0.085 & 0.082 \\
\hline Low-tech industries & 0.018 & 0.017 & 0.023 & 0.025 & 0.021 \\
\hline United Kingdom & 0.069 & 0.090 & 0.072 & 0.070 & 0.073 \\
\hline High-tech industries & 0.259 & 0.363 & 0.251 & 0.216 & 0.226 \\
\hline Medium-tech industries & 0.058 & 0.063 & 0.056 & 0.070 & 0.069 \\
\hline Low-tech industries & 0.019 & 0.016 & 0.011 & 0.012 & 0.013 \\
\hline United States & 0.082 & 0.093 & 0.108 & 0.097 & 0.099 \\
\hline High-tech industries & 0.309 & 0.303 & 0.324 & 0.270 & 0.275 \\
\hline Medium-tech industries & 0.070 & 0.081 & 0.075 & 0.084 & 0.082 \\
\hline Low-tech industries & 0.015 & 0.019 & 0.019 & 0.017 & 0.018 \\
\hline
\end{tabular}

R\&D intensity is computed as $R \& D$ /value added. The high-tech industries are Aerospace (3845), Office and computing equipment (3825), Electrical machinery (383-3832), Pharmaceuticals (3522) and Instruments (385). The medium-tech industries are Other chemicals $(351+352-3522)$, Rubber and plastic products $(355+356)$, Nonferrous metals (372), Nonelectrical machinery (382-3825), Radio, TV and communication equipment (3832), Automobiles (3843), Other transport (384-3841-3843-3845) and Other manufacturing (39). The lowtech industries are Food, beverages and tobacco (31), Textiles, apparel and leather (32), Wood products and furniture (33), Paper, paper products and printing (34), Refined oil and related products $(353+354)$, Glass, stone and clay (36), Ferrous metals (371), Metal products (381) and Shipbuilding (3841).

and low-tech industries depending on an industry's R\&D-intensity. ${ }^{7}$ In Table 1, we report the R\&D intensities of these three levels of technological advancement and a country's total $R \& D$ intensity in manufacturing. R\&D intensity is defined as the ratio of spending on

7 The high-tech industries are Aerospace (3845), Office and computing equipment (3825), Electrical machinery (383-3832), Pharmaceuticals (3522) and Instruments (385). The medium-tech industries are Other chemicals $(351+352-3522)$, Rubberand plastic products $(355+356)$, Nonferrousmetals(372), Nonelectricalmachinery $(382-$ 3825), Radio, TV and communication equipment (3832), Automobiles (3843), Other transport (384-3841-38433845) and Other manufacturing (39). The low-tech industries are Food, beverages and tobacco (31), Textiles, apparel and leather (32), Wood products and furniture (33), Paper, paper products and printing (34), Refined oil and related products (353 + 354), Glass, stone and clay (36), Ferrous metals (371), Metal products (381) and Shipbuilding (3841). 
R\&D in year $t$ and an industry's value added in the same year. From the intensities reported in Table 1, it is clear that R\&D intensity is highest in US manufacturing and lowest in Finnish manufacturing. In addition, R\&D intensity is highest in the high-tech industries in all countries and comparable ratios, relative to total $R \& D$ intensity, are obtained for all countries. R\&D intensity in the low-tech industries lies between $1 \%$ and $2.5 \%$, whereas $\mathrm{R} \& \mathrm{D}$ intensity in the high-tech industries is much higher and dispersed between countries (between $11 \%$ and $36 \%$ ).

Third, the Bilateral Trade database (BTD) (OECD, 1998a) for international trade data is used to calculate import shares as applied in our spillover analysis. For 23 OECD countries, BTD shows both imports and exports by industry from one country (or geographical area) to another.

Fourth, data on skill decomposition were provided by the OECD secretariat and described in a detailed way in a OECD background paper by Colecchia and Papaconstantinou (1996). We divide the manufacturing workforce into four categories: white-collar high- and low-skilled and blue-collar high- and low-skilled labour. In the cases where data were available in ISCO-88 format, occupations were aggregated by the OECD secretariat at different levels as follows: White-collar high-skilled: legislators, senior officials and managers, professionals, technicians and associate professionals (including scientists and engineers). White-collar low-skilled: clerks, service workers, shop and market sales workers. Blue-collar high-skilled: skilled agricultural and fishery workers, craft and related trade workers. Blue-collar low-skilled: plant and machine operators and assemblers, elementary occupations. In Table 2, we report the employment shares of high-skilled and nonproduction workers for each country. High-skilled workers are defined as whitecollar and blue-collar high-skilled workers, and nonproduction workers are defined as white-collar workers. From Table 2, it can be read that there are substantial differences in the employment shares and that it is likely to influence the analysis of changing employment shares. For example, the high-skilled workers' employment shares in Finland and Japan are (more than) twice the employment shares of nonproduction workers. For the United States, both employment shares are rather comparable, whereas the employment shares differ also substantially in France, Germany and the United Kingdom. Hence, a priori, it seems quite natural and important to distinguish between different definitions of "skilled" labour.

Finally, patent application data by the European Patent Office (EPO) are used to measure knowledge spillovers between industries by means of a patent spillover matrix (Verspagen, 1997b). An EPO patent is assigned several International Patent Classification (IPC) codes, one main IPC code, referring to the technological class that best describes the main application of the knowledge claimed in the patent, and several supplementary IPC codes, referring to other technological classes best describing supplementary knowledge described by the patent. The patent spillover matrix is calculated by first assigning each patent to a specific industry by using a concordance scheme between IPC codes and ISIC codes. $^{8}$ The main IPC codes were used to identify the producing or spillover-generating

\footnotetext{
8 Almost 400,000 patent applications over the period 1979-1994 are used in constructing the patent spillover matrix.
} 
Table 2

High-skilled and nonproduction workers' employment shares in manufacturing, 1975-1995

\begin{tabular}{|c|c|c|c|c|c|}
\hline & 1975 & 1980 & 1985 & 1990 & 1995 \\
\hline \multicolumn{6}{|l|}{ Finland } \\
\hline High-skilled workers & 0.581 & 0.582 & 0.601 & 0.616 & \\
\hline Nonproduction workers & 0.271 & 0.273 & 0.324 & 0.351 & \\
\hline \multicolumn{6}{|l|}{ France } \\
\hline High-skilled workers & & 0.384 & 0.413 & 0.445 & \\
\hline Nonproduction workers & & 0.295 & 0.319 & 0.345 & \\
\hline \multicolumn{6}{|l|}{ Germany } \\
\hline High-skilled workers & & 0.529 & 0.554 & 0.575 & \\
\hline Nonproduction workers & & 0.318 & 0.345 & 0.362 & \\
\hline \multicolumn{6}{|l|}{ Japan } \\
\hline High-skilled workers & & 0.709 & 0.669 & 0.663 & \\
\hline Nonproduction workers & & 0.290 & 0.309 & 0.341 & \\
\hline \multicolumn{6}{|l|}{ United Kingdom } \\
\hline High-skilled workers & & 0.535 & 0.557 & 0.571 & 0.594 \\
\hline Nonproduction workers & & 0.339 & 0.364 & 0.364 & 0.389 \\
\hline \multicolumn{6}{|l|}{ United States } \\
\hline High-skilled workers & & 0.380 & 0.383 & 0.388 & 0.396 \\
\hline Nonproduction workers & & 0.331 & 0.334 & 0.342 & 0.320 \\
\hline
\end{tabular}

High-skilled workers are defined as legislators, senior officials and managers, professionals, technicians and associate professionals, skilled agricultural and fishery workers and craft and related trade workers. Nonproduction workers are defined as legislators, senior officials and managers, professionals, technicians and associate professionals, clerks, service workers and shop and market sales workers. France refers to 1982, 1985 and 1990, the United Kingdom to 1981, 1984, 1988 and 1992 and the United States to 1983, 1985, 1990 and 1994.

industry, and the supplementary IPC codes to identify the knowledge- or spilloverreceiving industries. The value in each cell in the spillover matrix, as shown in the Appendix $\mathrm{A}$ at the end of this paper, is equal to the ratio of the number of patents assigned to the combination of the producing and receiving industry divided by the row total. As such, each cell represents the fraction of total patents produced by one industry spilling over to another industry. ${ }^{9}$ Calculating column totals shows that Office and computing equipment, Pharmaceuticals, Instruments, Metal products and Automobiles are the largest spillover-receiving industries, whereas generally the industries with the lowest R\&D intensities are receiving the least spillovers from other sectors.

The measurement of technology is a well-known problem. Many studies rely upon input measures such as the R\&D intensity ( $\& \& D$ relative to value added) of a firm, industry or country to measure productivity. In doing so, they are not able to measure the efficiency of the R\&D process and the spillover effects the innovation process generates.

\footnotetext{
9 It is important to note that the diagonal of the matrix with respect to the calculation of the domestic knowledge stock is put at zero to exclude the problem of multicollinearity.
} 
Efficiency has been measured by looking for example at patent counts and spillovers have been measured by investigating R\&D efforts by other firms, industries or countries. In this paper, we follow a strategy developed in Verspagen (1997a) to capture the inputs, efficiency and spillovers of the process of innovation. We do so by taking into account knowledge spillovers from one industry to the other, as described by the matrix discussed above.

Griliches (1979) made a distinction between rent spillovers and knowledge spillovers. Rent spillovers are caused by the fact that the producer of the innovation is unable to capture the full rents resulting from the new product. Knowledge spillovers are more central to the debate on the changing employment structures observed since the $1980 \mathrm{~s}$. In contrast to rent spillovers, knowledge spillovers are not embodied in goods, and thus do not occur in relation to market transactions. Knowledge spillovers are related to the partly public character of knowledge and may occur when information is exchanged between people of different firms at, e.g. conferences, when a worker moves from one plant to another, or when a patent is disclosed. The most important property of such spillovers is that the relevant knowledge is transferred from one firm to another, without the receiving firm having to pay for it.

To construct an estimate of the industry R\&D spillovers, Jaffe (1986) has introduced a technical similarity method that measures for each firm the available pool of outside R\&D, with the R\&D of other firms being weighted inversely to their estimated technical distance from each others research results. Here we apply a similar method to measure "knowledge" spillovers using a technology flow matrix (available from Appendix A). The technology class is taken as an indicator of the industry that generates the knowledge, and the supplementary technology class is taken as an indicator of a spillover-receiving firm. This matrix is used to construct "indirect R\&D stocks" by summing R\&D performed by firms in different industrial sectors and different countries, which enables us to measure the extent to which an industry profits from R\&D efforts in another industry. ${ }^{10}$ This is a more rigorous approach than the one applied in Coe and Helpman (1995), because we assume a more advanced weighting scheme for sectoral technology linkages; these linkages are based on the data compiled from the EPO data. Their analysis is also modified here, because the matrix is used in such a way that it is able to capture intersectoral spillovers, while import shares capture the international extent and distribution of spillovers. Coe and Helpman (1995) implicitly use equal fixed weights for both measures by not splitting them in these two components. ${ }^{11}$

\footnotetext{
10 The construction of the matrix used here can be compared to Scherer's technology flow tables (Scherer, 1982) and to the one known as the Yale matrix constructed by Putnam and Evenson (1994) and applied by Kortum and Putnam (1997). However, the Yale matrix is aimed at measuring "rent" spillovers, while the matrix we use is aimed at measuring "knowledge" spillovers. Two other matrices constructed by Verspagen (1997b) are aimed at (i) measuring "rent" spillovers, as in Griliches (1979), and (ii) measuring spillovers on the basis of patent citation information using data from the United States Patent and Trademark Office (USPTO), as in Putnam and Evenson (1994). These latter two measures can be considered special cases of the measures of knowledge spillovers we consider.

11 Keller (1998) also provides a critical assessment of the findings of Coe and Helpman (1995). He finds that it is doubtful that patterns of international trade by themselves are important in driving R\&D spillovers.
} 


\section{Econometric model}

Much of the empirical literature investigating changes in the employment structure are done in the context of a flexible functional form. The most popular functional form is the translog model, which is often interpreted as a second-order approximation to an unknown functional form. ${ }^{12}$ Following the initial approach of Christensen et al. (1973), assume that the employment share of group $s$ is a function $s=g\left(\ln x_{1}, \ldots, \ln x_{Q}\right)$. Then, by expanding this function in a second-order Taylor series around the mean of the respective $x$ 's and interpreting the derivatives as coefficients, we obtain

$$
s=\beta_{0}+\sum_{q=1}^{Q} \beta_{q} \ln x_{q}+\frac{1}{2} \sum_{q=1}^{Q} \sum_{r=1}^{Q} \gamma_{q r} \ln x_{q} \ln x_{r}+\varepsilon .
$$

Eq. (1) is the equation we would like to estimate. In this equation, $s$ is the employment share of a group of workers and the group of $x$ 's one might think of are the capital stock, value added, the relative wage rate of this group and measures of technology such as R\&D intensity, the number of patents and spillovers from one sector to the other.

In particular, the function explaining the employment share of skilled workers in industry $i$ in country $j$ in year $t$ is

$$
s_{i j t}=\beta_{0 i j}+\beta_{1 j} \ln K_{i j t}+\beta_{2 j} \ln Y_{i j t}+\beta_{3 j} T E C H_{i j t}+\beta_{4 j} \ln \left(W^{s} / W^{u}\right)_{i j t},
$$

where $Y_{i j t}$ is value added, $K_{i j t}$ is the physical capital stock, $T E C H_{i j t}$ is a measure of the stock of technology and $W$ are the wage rates for skilled and unskilled workers.

There are two problems we have to encounter before estimating Eq. (2). The first problem with estimating Eq. (2) is the correlated industry-specific fixed effect $\beta_{0 i j}$. This problem can be overcome by time differencing Eq. (2). The second problem is the wage variables. Estimating employment shares, wages are endogenous and might therefore lead to estimation results that have to be interpreted with caution. In the absence of an appropriate instrument, Machin and Van Reenen (1998) suggest to replace the relative wage rates by country-specific time dummies $D_{j t}$. Another important observation from Eq. (2) is that $s_{i j t}$ reflects the share of skilled workers in total employment, not total costs. This allows us to estimate the equation under the assumption that the underlying production function is assumed to exist of only two variable factors of production, i.e. skilled and unskilled labour. Capital and technology stocks are assumed to be quasi-fixed (see, e.g. Adams, 1999). Encountering both

12 See, e.g. Betts (1997), Machin and Van Reenen (1998), Adams (1999) and Goux and Maurin (2000). Betts (1997) estimates a model to show to what extent technological change has been neutral in Canadian manufacturing. Adams (1999) investigates whether research and development and capital lead to a skill bias in US manufacturing. Goux and Maurin (2000) apply a translog function to see whether technological change has been neutral in France over the past 30 years. Finally, the paper by Machin and Van Reenen (1998) comes closest to our analysis. They estimate to what extent technological change is causing wage inequality and changes in the employment structure of France, Germany, Japan, Sweden, the United Kingdom and the United States. 
problems and assuming capital and technology to be quasi-fixed, the equation for estimation becomes the following:

$$
\Delta s_{i j t}=\beta_{1 j} \Delta \ln K_{i j t}+\beta_{2 j} \Delta \ln Y_{i j t}+\beta_{3 j} \Delta T E C H_{i j t}+\beta_{4 j} D_{j t}+\varepsilon_{i j t},
$$

with the $\Delta$ 's being a difference operator and $\varepsilon_{i j t}$ a random error term.

The variable of main interest in this paper is $\triangle T E C H$. Most studies use the ratio of the flow of R\&D expenditures to value added as a measure of change in the technology stock. Some have also incorporated the number of patents granted to an industry relative to value added. These variables are crude approximations of the inputs (R\&D) and efficiency (patents) of the process of technology creation. However, most studies neglect the importance and potential scope for spillovers from one sector to the other. Since spillovers have been found important in explaining productivity in OECD countries, they are likely to be also important in explaining employment shares.

For the purpose of this paper, the three main problems in defining spillovers are the following. First, since spillovers are externalities arising from the public good nature of technology, it is hard to measure them. Second, putting R\&D spillovers, as most studies on spillovers do, and an industry's own R\&D in one equation might lead to identification problems. Third, using only R\&D spillovers captures the input of the innovation process but does not reveal any information on its success rate. To encounter these problems, we do not use a measure of spillovers based solely on "technology" but based on "knowledge".

First, the capital and own R\&D stock are determined, using the perpetual inventory method, as

$$
K_{t}=(1-\varphi) K_{t-1}+I_{K_{t}}
$$

and

$$
R D_{t}=(1-\chi) R D_{t-1}+I_{R D_{t}}
$$

where $\varphi$ and $\chi$ are the depreciation rates with respect to the capital and own R\&D stock, respectively, and $I_{K_{t}}$ and $I_{R D_{t}}$ equal the (annual) investments in both stocks. The initial capital and knowledge stocks are defined in the following manner $K_{0}=\left(I_{K_{1}}\right) /(\varphi+0.05)$ and $R D_{0}=\left(I_{R D_{1}}\right) /(\chi+0.05)$. This is in line with the definitions suggested by Griliches $(1980)$. Following Adams (1999), we take into account an annual depreciation rate of $5 \%$ for the capital stock and $15 \%$ for the knowledge stock. ${ }^{13}$

The domestic indirect knowledge stock (IRD) for industry $i$ is defined as

$$
I R D_{i t}=\sum_{k} \omega_{i k} R D_{k t}\left(1-m_{k t}\right),
$$

and the foreign knowledge stock $(I R F)$ for the same industry is defined as

$$
I R F_{i t}=\sum_{f=1}^{F} \sum_{k} \omega_{i k} R D_{f k t} n_{f k t} m_{k t} .
$$

\footnotetext{
13 Taking other reasonable rates of depreciation does not change the estimation results substantially.
} 
In Eqs. (6) and (7), $\omega_{i k}$ is defined as the part of R\&D performed by sector $k$ that spills over to sector $i$ using the values in row $i$ and column $k$ of the spillover matrix ${ }^{14}$ and $m_{k}$ is the import weight of sector $k$, relative to total imports of sector $k$ in all countries. In Eq. (7), $F$ is the number of trading partners that are taken into consideration, in this case 13 . We assume 14 OECD countries from which trade occurs. Besides Finland, France, Germany, Japan, the United Kingdom and the United States, these countries are Australia, Canada, Denmark, Italy, the Netherlands, Norway, Spain and Sweden. We are aware that some trade is neglected by taking only 14 countries, but on average, over $90 \%$ of all trade between industries is covered. The variable labelled $n_{f k}$ gives us the import share of sector $k$ in country $f$ 's total imports. The import weight $m_{k}$ is taken as an indicator of the degree of interaction between the countries involved, which is likely to have an impact in terms of to what extent spillovers flow between countries. Finally, we use stocks rather than flows because we assume knowledge to be cumulative. Changes in knowledge are therefore due to depreciation of knowledge and investments in new knowledge.

\section{Results}

\subsection{Basic regression}

In the literature, positive correlations have been reported between $R \& D$ intensity and the employment of more skilled workers and between increasing levels of R\&D effort and skill upgrading. In Table 3, the results of a regression only including R\&D intensity as an explanatory variable for the changing employment structure are reported. We estimated a model of 5-year changes for each of the six countries. Each equation also includes a set of country dummies to control for country-specific shocks and is weighted by industry size. In the table we report estimates for three different dependent variables. The first column reports regressions taking high-skilled workers (high-skilled white-collar and blue-collar workers) as the dependent variable. The second column includes only white-collar highskilled workers and the third column nonproduction workers (white-collar workers). Taking nonproduction workers as the dependent variable to define changes in the employment shares of skilled workers is consistent with the studies of Berman et al. (1998), Machin and Van Reenen (1998) and Berman and Machin (2000). For each country, we have first estimated the total effect of R\&D intensity on employment shares. We also estimated the effects of R\&D intensity on the employment shares in high-tech industries and low-tech industries separately, except for Germany and Japan where too little information for high-tech industries is available.

Consistent with the estimates reported in the literature, in all cases (but one), the estimated coefficients on the R\&D variable are positive and in most cases significant at the $5 \%$ level. For the full sample of each country, only the coefficients for France, Japan, the United Kingdom and the United States (high-skilled workers) and the nonproduction workers in Japan are not significantly positive at the 5\% level. The coefficients for the employment shares of high-skilled workers are worse than the coefficients found for

\footnotetext{
14 Note that as the diagonal of the spillover matrix is put at zero, $\omega_{j j}=0$.
} 
Table 3

Basic regressions of changes in high-skilled, white-collar high-skilled and nonproduction workers' employment shares on R\&D intensity (5-year changes)

\begin{tabular}{|c|c|c|c|c|c|}
\hline & & $\begin{array}{l}\text { Changes in high-skilled } \\
\text { employment shares }\end{array}$ & $\begin{array}{l}\text { Changes in white-collar } \\
\text { high-skilled employment } \\
\text { shares }\end{array}$ & $\begin{array}{l}\text { Changes in } \\
\text { nonproduction } \\
\text { employment shares }\end{array}$ & $\begin{array}{l}\text { Sample } \\
\text { size }\end{array}$ \\
\hline \multirow[t]{3}{*}{ Finland } & Total & $0.013(0.004)^{*}$ & $0.025(0.003)^{*}$ & $0.018(0.005)^{*}$ & 66 \\
\hline & $\begin{array}{l}\text { High-tech } \\
\text { industries }\end{array}$ & $0.019(0.012)$ & $0.033(0.012)^{*}$ & $0.024(0.012)^{*}$ & 15 \\
\hline & $\begin{array}{l}\text { Low-tech } \\
\text { industries }\end{array}$ & $0.011(0.007)$ & $0.020(0.003)^{*}$ & $0.015(0.005)^{*}$ & 27 \\
\hline \multirow[t]{3}{*}{ France } & Total & $0.035(0.020)$ & $0.046(0.018)^{*}$ & $0.035(0.007)^{*}$ & 44 \\
\hline & $\begin{array}{l}\text { High-tech } \\
\text { industries }\end{array}$ & $0.137(0.065)^{*}$ & $0.150(0.058)^{*}$ & $0.140(0.062)^{*}$ & 10 \\
\hline & $\begin{array}{l}\text { Low-tech } \\
\text { industries }\end{array}$ & $0.029(0.025)$ & $0.029(0.025)$ & $0.028(0.025)$ & 18 \\
\hline \multirow[t]{2}{*}{ Germany } & $\begin{array}{l}\text { Total } \\
\text { High-tech } \\
\text { industries }\end{array}$ & $0.027(0.006)^{*}$ & $0.017(0.004)^{*}$ & $0.021(0.007)^{*}$ & 36 \\
\hline & $\begin{array}{l}\text { Low-tech } \\
\text { industries }\end{array}$ & $0.024(0.006)^{*}$ & $0.018(0.004)^{*}$ & $0.020(0.004)^{*}$ & 16 \\
\hline \multirow[t]{2}{*}{ Japan } & $\begin{array}{l}\text { Total } \\
\text { High-tech } \\
\text { industries }\end{array}$ & $0.012(0.019)$ & $0.022(0.007)^{*}$ & $0.013(0.009)$ & 38 \\
\hline & $\begin{array}{l}\text { Low-tech } \\
\text { industries }\end{array}$ & $0.009(0.015)$ & $0.020(0.007)^{*}$ & $0.012(0.010)$ & 18 \\
\hline \multirow[t]{3}{*}{ United Kingdom } & Total & $0.015(0.008)$ & $0.030(0.011)^{*}$ & $0.022(0.010)^{*}$ & 66 \\
\hline & $\begin{array}{l}\text { High-tech } \\
\text { industries }\end{array}$ & $0.051(0.023)^{*}$ & $0.093(0.033)^{*}$ & $0.070(0.023)^{*}$ & 15 \\
\hline & $\begin{array}{l}\text { Low-tech } \\
\text { industries }\end{array}$ & $0.020(0.027)$ & $0.026(0.012)^{*}$ & $0.021(0.012)$ & 27 \\
\hline \multirow[t]{3}{*}{ United States } & Total & $0.037(0.025)$ & $0.052(0.020)^{*}$ & $0.047(0.020)^{*}$ & 63 \\
\hline & $\begin{array}{l}\text { High-tech } \\
\text { industries }\end{array}$ & $0.074(0.009)^{*}$ & $0.075(0.011)^{*}$ & $0.075(0.011)^{*}$ & 15 \\
\hline & $\begin{array}{l}\text { Low-tech } \\
\text { industries }\end{array}$ & $-0.013(0.019)$ & $0.008(0.003)^{*}$ & $0.007(0.003)^{*}$ & 24 \\
\hline
\end{tabular}

Standard errors in parentheses. The time periods for Finland concerning the employment shares are 1975-1980, 1980-1985 and 1985-1990; for France 1982-1985 and 1985-1990; for Germany and Japan 1980-1985 and 1985-1990; for the United Kingdom 1981-1984, 1986-1988 and 1988-1992; and for the United States 19831985, 1985-1990 and 1990-1994.

* Significant at the $5 \%$ level.

nonproduction workers, except for Germany. This might indicate that particularly whitecollar workers benefit in terms of employment shares from R\&D efforts, whereas highskilled blue-collar workers do not seem to benefit as much from innovation efforts. If we investigate the employment shares of white-collar high-skilled workers only, it turns out that their employment shares reveal a higher and more significant correlation with $R \& D$ intensity, except for Germany. These results may not come as a surprise since scientists and engineers are included in the group of high-skilled white-collar workers. It seems 
rather obvious that their employment shares increase when a firm decides to put more effort into the process of research and development. ${ }^{15}$

Decomposing the effects of R\&D intensity on employment shares of more-skilled workers by technology advancement of a sector shows that in the high-tech industries, there is a stronger and significant relationship between R\&D intensity and the employment shares of more-skilled workers. For most countries, the coefficients are positive and significant at the 5\% level for the high-tech industries (except for high-skilled workers in Finland). For the low-tech industries, the correlations are not so obvious and the results show a mixed pattern. For some definitions of more-skilled workers, like white-collar high-skilled workers, we find positive and significant results in all cases, except for France; for the high-skilled workers, none of the coefficients are significant at the 5\% level. The coefficients for nonproduction workers suggest positive and significant results, except for France, Japan and the United Kingdom. ${ }^{16}$

Our overall reading of these results is that there seems to be a positive relationship between skill upgrading and R\&D efforts. From decomposing the industries into high-tech and low-tech industries, the results suggest that in all six countries, industries with higher R\&D intensities have upgraded their workforce faster. However, the coefficients are somewhat sensitive to the definition of "skilled" workers. ${ }^{17}$ Taking the change in the employment share of high-skilled workers as the dependent variable leads to less convincing results than using the change in the employment share of white-collar highskilled workers; using the change in the employment share of nonproduction workers provides results that lie in between. We view the fact that a significant correlation is obtained for the employment shares of more skilled workers as a reassuring observation for interpreting the observed changes in "skilled" workers' employment shares. However, there does not seem to be a direct link between a worker's job and R\&D intensity, except for scientists and engineers. Investigating the changes in employment shares of skilled workers based on their occupational level (defined as high-skilled workers) leads to less significant results and makes the correlation between "skill" and "technology" less clear. For example, an implication that can be directly drawn from these findings is that a secretary (nonproduction worker) working in a firm that devotes relatively many resources to the process of R\&D (high-tech industry) faced an increase in her employment share relative to the same secretary employed in a firm that spends less on R\&D (low-tech industry). This seems to be hard to understand and it seems likely therefore that a more

15 The correlation between the employment shares of scientists and engineers and R\&D intensity is indeed higher than the correlation between the employment shares of white-collar high-skilled workers and R\&D intensity.

16 These estimates confirm the results presented by Berman et al. (1998), Machin and Van Reenen (1998) and Berman and Machin (2000) for both OECD and developing countries. However, it is hard to compare the estimates because they use a different definition of R\&D intensity and cover a different time period. They are also consistent with the estimates presented by Doms et al. (1997) and Autor et al. (1998) for the United States and Machin (1996) for the United Kingdom. Estimates for the Netherlands over the period 1986-1998 by Bruinshoofd et al. (2001) are also comparable to the estimates here.

17 We also tested whether the coefficients on R\&D intensity between countries are statistically different from one another. We are not able to statistically discriminate between the coefficients at the $5 \%$ level, but in most cases we are able to discriminate between the coefficients at the $10 \%$ level. 
direct measure of technology application or use is more appropriate to use, when we want to examine and understand the correlation between skill and technology. In the next section, we use knowledge spillovers to investigate to what extent the application and spread of technology is a determinant to explain the observed patterns.

\subsection{Estimation results including knowledge spillovers}

Table 4 reports the regression results of estimating Eq. (3). In Eq. (3) we include, besides capital $K$ and value added $Y, \mathrm{R} \& \mathrm{D}$ intensity $R D / Y$ and the two measures of knowledge spillovers: IRD/Y are domestic knowledge spillovers or the domestic indirect knowledge stock and $I R F / Y$ are international knowledge spillovers or the foreign international knowledge stock. The regressions are performed by country and shown for the three types of employment shares we also distinguished above. Because of lack of a sufficient number of observations, we are not able to report results by country based on a distinction between high-tech and low-tech industries. ${ }^{18}$ Table 5 therefore reports those results for all countries pooled together. ${ }^{19}$

The regression results reported in Table 4 show in all instances a positive and significant relationship between changes in the employment shares and R\&D intensity. Consistent with the results presented in Table 3, the point estimates are highest in all countries (except for Germany) for the change in the employment share of white-collar high-skilled workers. This provides evidence that is very much in line with the hypothesis of skill-biased technological change that there is a positive relationship between new technology and changes in employment structures. However, the point estimates are of a much smaller magnitude. Comparing these coefficients to the coefficients reported by Machin and Van Reenen (1998), we find in general smaller effects of R\&D intensity on changes in the employment shares of skilled workers. In the second column, the coefficients on capital are reported. The interpretation of these coefficients is that it reveals information about the embodied part of technological change. New technology embodied in recent vintages of capital equipment is likely to correlate positively with the employment share of skilled workers (e.g. Krusell et al., 2000). We find this positive correlation between the employment share of skilled workers and capital growth except for Germany and Japan. For France and the United States, capital growth contributes positively and significantly to the change in the employment share of skilled workers, whereas in Finland and the United Kingdom, the point estimates are positive but not significant at the $5 \%$ level.

The coefficients on the knowledge spillover variables are of main interest. For the domestic knowledge spillovers, we find positive and significant results in almost all instances. Only for the employment shares of high-skilled and nonproduction workers in

18 Given that most of the upgrading takes place within sectors and that in each sector we might observe some persistent employment dynamics, we test the hypothesis that the change in the skill composition in each industry of manufacturing will follow the general upgrading trend in manufacturing with some deviations from it.

19 In an earlier version of this paper, we also tested models in which we imposed constant returns to scale, i.e. $\beta_{1 j}=-\beta_{2 j}$ (see Hollanders and ter Weel, 2000, Table 2). The results indicate that including $\Delta \ln (K / Y)$, instead of $\Delta \ln K$ and $\Delta \ln Y$ separately, in most cases leads to the conclusion that we cannot reject the hypothesis of constant returns to scale. 
Table 4

Changes in the high-skilled workers' employment shares in manufacturing, 1975-1995 (5-year changes)

\begin{tabular}{|c|c|c|c|c|c|c|c|}
\hline & & $R D / Y$ & $\Delta \ln K$ & $\Delta \ln Y$ & $I R D / Y$ & $I R F / Y$ & $\begin{array}{l}\text { Sample } \\
\text { size }\end{array}$ \\
\hline \multirow[t]{3}{*}{ Finland } & High-skilled workers & $0.008(0.004)^{*}$ & $0.026(0.015)$ & $-0.069(0.018)^{*}$ & $0.004(0.002)^{*}$ & $0.001(0.001)$ & 66 \\
\hline & White-collar high-skilled workers & $0.012(0.004)^{*}$ & $0.020(0.012)$ & $-0.072(0.019)^{*}$ & $0.008(0.002)^{*}$ & $0.005(0.002)^{*}$ & 66 \\
\hline & Nonproduction workers & $0.011(0.004)^{*}$ & $0.019(0.012)$ & $-0.068(0.021)^{*}$ & $0.006(0.003)^{*}$ & $0.001(0.002)$ & 66 \\
\hline \multirow[t]{3}{*}{ France } & High-skilled workers & $0.020(0.009)^{*}$ & $0.052(0.016)^{*}$ & $-0.001(0.012)$ & $0.009(0.004)^{*}$ & $0.009(0.005)^{*}$ & 44 \\
\hline & White-collar high-skilled workers & $0.023(0.009)^{*}$ & $0.053(0.017)^{*}$ & $-0.002(0.011)$ & $0.013(0.003)^{*}$ & $0.012(0.004)^{*}$ & 44 \\
\hline & Nonproduction workers & $0.020(0.008)^{*}$ & $0.050(0.016)^{*}$ & $-0.001(0.010)$ & $0.010(0.004)^{*}$ & $0.010(0.005)^{*}$ & 44 \\
\hline \multirow[t]{3}{*}{ Germany } & High-skilled workers & $0.012(0.004)^{*}$ & $-0.019(0.012)$ & $-0.000(0.007)$ & $0.009(0.004)^{*}$ & $0.009(0.005)^{*}$ & 36 \\
\hline & White-collar high-skilled workers & $0.008(0.003)^{*}$ & $-0.018(0.012)$ & $-0.001(0.006)$ & $0.006(0.003)^{*}$ & $0.006(0.003)$ & 36 \\
\hline & Nonproduction workers & $0.009(0.004)^{*}$ & $-0.021(0.013)$ & $-0.000(0.007)$ & $0.008(0.003)^{*}$ & $0.007(0.003)^{*}$ & 36 \\
\hline \multirow[t]{3}{*}{ Japan } & High-skilled workers & $0.012(0.004)^{*}$ & $-0.045(0.021)^{*}$ & $0.032(0.010)^{*}$ & $0.004(0.003)$ & $0.005(0.002)^{*}$ & 38 \\
\hline & White-collar high-skilled workers & $0.015(0.004)^{*}$ & $-0.046(0.022)^{*}$ & $0.028(0.011)^{*}$ & $0.007(0.003) *$ & $0.007(0.003)^{*}$ & 38 \\
\hline & Nonproduction workers & $0.012(0.005)^{*}$ & $-0.051(0.023)^{*}$ & $0.033(0.012)^{*}$ & $0.006(0.003)$ & $0.006(0.003)^{*}$ & 38 \\
\hline \multirow[t]{3}{*}{ United Kingdom } & High-skilled workers & $0.013(0.006)^{*}$ & $0.021(0.012)$ & $0.034(0.016)^{*}$ & $0.002(0.001)$ & $0.001(0.001)$ & 66 \\
\hline & White-collar high-skilled workers & $0.020(0.010)^{*}$ & $0.022(0.012)$ & $0.032(0.016)^{*}$ & $0.009(0.003)^{*}$ & $0.005(0.002)^{*}$ & 66 \\
\hline & Nonproduction workers & $0.015(0.007)^{*}$ & $0.021(0.012)$ & $0.032(0.016)^{*}$ & $0.004(0.002)$ & $0.003(0.001)^{*}$ & 66 \\
\hline \multirow[t]{3}{*}{ United States } & High-skilled workers & $0.030(0.015)^{*}$ & $0.049(0.019)^{*}$ & $-0.011(0.009)$ & $0.005(0.005)$ & $0.002(0.002)$ & 68 \\
\hline & White-collar high-skilled workers & $0.035(0.015)^{*}$ & $0.050(0.020)^{*}$ & $-0.012(0.008)$ & $0.007(0.003)^{*}$ & $0.005(0.002)^{*}$ & 68 \\
\hline & Nonproduction workers & $0.032(0.016)^{*}$ & $0.050(0.020)^{*}$ & $-0.012(0.008)$ & $0.005(0.003)$ & $0.004(0.002)$ & 68 \\
\hline
\end{tabular}

Heteroskedasticity-consistent standard errors in parentheses. When we test for constant returns to scale, this hypothesis cannot be rejected. The time periods for Finland concerning the employment shares are 1975-1980, 1980-1985 and 1985-1990; for France 1982-1985 and 1985-1990; for Germany and Japan 1980-1985 and 19851990; for the United Kingdom 1981-1984, 1986-1988 and 1988-1992; and for the United States 1983-1985, 1985-1990 and 1990-1994.

* Significant at the 5\% level. 
Table 5

Changes in employment shares in manufacturing within different industries selected on the basis of technological advancement, 1975 -1995 (5-year changes)

\begin{tabular}{|c|c|c|c|c|c|c|c|}
\hline & & $R D / Y$ & $\Delta \ln K$ & $\Delta \ln Y$ & $\operatorname{IRD} / Y$ & $I R F / Y$ & Sample size \\
\hline \multirow[t]{3}{*}{ All countries } & High-skilled workers & $0.018(0.006)^{*}$ & $0.026(0.015)$ & $0.013(0.012)$ & $0.006(0.002)^{*}$ & $0.005(0.002)^{*}$ & 313 \\
\hline & High-tech industries & $0.030(0.008)^{*}$ & $0.032(0.016)$ & $0.012(0.011)$ & $0.005(0.002)^{*}$ & $0.004(0.002)^{*}$ & 65 \\
\hline & Low-tech industries & $0.006(0.004)$ & $0.021(0.015)$ & $0.008(0.008)$ & $0.006(0.002)^{*}$ & $0.006(0.001)^{*}$ & 130 \\
\hline \multirow[t]{3}{*}{ All countries } & White-collar high-skilled workers & $0.020(0.007)^{*}$ & $0.028(0.015)$ & $0.014(0.007)$ & $0.008(0.003)^{*}$ & $0.007(0.003)^{*}$ & 313 \\
\hline & High-tech industries & $0.043(0.009)^{*}$ & $0.034(0.016)^{*}$ & $0.013(0.011)$ & $0.007(0.002)^{*}$ & $0.006(0.002)^{*}$ & 65 \\
\hline & Low-tech industries & $0.008(0.004)$ & $0.020(0.015)$ & $0.010(0.010)$ & $0.007(0.003)^{*}$ & $0.008(0.002)^{*}$ & 130 \\
\hline \multirow[t]{3}{*}{ All countries } & Nonproduction workers & $0.019(0.006)^{*}$ & $0.026(0.015)$ & $0.015(0.012)$ & $0.006(0.001)^{*}$ & $0.007(0.003)^{*}$ & 313 \\
\hline & High-tech industries & $0.032(0.008)^{*}$ & $0.032(0.015)^{*}$ & $0.015(0.008)$ & $0.005(0.002)^{*}$ & $0.005(0.002)^{*}$ & 65 \\
\hline & Low-tech industries & $0.006(0.004)$ & $0.020(0.014)$ & $0.008(0.008)$ & $0.006(0.002)^{*}$ & $0.007(0.002)^{*}$ & 130 \\
\hline
\end{tabular}

Heteroskedasticity-consistent standard errors in parentheses. In the regression analysis, the countries have been pooled. When we test for constant returns to scale, this hypothesis cannot be rejected. The time periods for Finland concerning the employment shares are 1975-1980, 1980-1985 and 1985-1990; for France 1982-1985 and 1985-1990; for Germany and Japan 1980-1985 and 1985-1990; for the United Kingdom 1981-1984, 1986-1988 and 1988-1992; and for the United States 1983$1985,1985-1990$ and $1990-1994$.

* Significant at the $5 \%$ level. 
Japan, the United Kingdom and the United States, the results are not significant at the 5\% level. For the knowledge spillovers from abroad, we obtain also significant and positive coefficients except for high-skilled workers in Finland, the United Kingdom and the United States, for white-collar high-skilled workers in Germany and for nonproduction workers in Finland and the United States. ${ }^{20}$ These results point towards a nonnegligible role of knowledge spillovers in explaining the changes in the employment of skilled workers. ${ }^{21}$ Not only the development of new technologies captured by measures of R\&D inputs in the process of innovation but also the application of new technologies captured by the knowledge spillovers seem to be important in explaining skill upgrading. Although the coefficients on the spillover variables are smaller than the coefficients on the R\&D variable, this result also stresses the importance of distinguishing between the process of $\mathrm{R} \& \mathrm{D}$, which requires by definition scientists and engineers and the spread and use of the new technology from which it is not a priori obvious that it requires more skilled workers. Our results suggest that both the development and use (as measured by spillovers) of new technology is skill-biased. ${ }^{22}$

Although these results present an intriguing perspective on the relationship between technology and skill upgrading in several countries, it does not reveal any information about the effects for different industries with different R\&D efforts. In Table 5, we pooled the data and distinguish between high-tech and low-tech industries. In addition, we distinguish between three dependent variables: changes in the employment shares of (i) high-skilled workers, (ii) white-collar high-skilled workers and (iii) nonproduction workers.

The results reported in Table 5 show significant coefficients for R\&D intensity in all instances, except for the low-tech sample. This result suggests that skill upgrading resulting from efforts addressed towards the process of $R \& D$ is typically observed in high-tech industries, whereas an amplification in the creation of new technologies in low-tech industries (if any) is not (significantly) characterized by skill upgrading. The coefficients on the spillover variables are all significant at the 5\% level. These coefficients, although generally smaller in magnitude than the coefficients on the R\&D variable, suggest that skill upgrading is also likely to be the result of spillover effects. Particularly when looking at the regression results for the low-tech sample, our reading is that spillover effects are more important in explaining skill upgrading than the development of new technologies (measured by R\&D intensity). From these results, we may conclude that the use of new technologies, created in other industries, in lowtech industries is explaining the patterns of skill upgrading, whereas the creation and development of new technologies is generating skill upgrading in the high-tech

\footnotetext{
20 We tested for the joint significance of all three technology variables and find that they are jointly significant in all instances. We also tested for differences between countries in the technology variables explaining the skill upgrading. The tests reveal that we cannot reject the hypothesis that the technology variables are similar.

21 The reader might be concerned with the potential endogeneity of R\&D and the spillover variables. We therefore also considered regression equations in which the R\&D and spillover variables from the first year for which we have skill data are considered. Several specifications of this approach yield results still revealing a positive correlation between skill upgrading and the technology variables.

22 Bruinshoofd et al. (2001) perform a similar analysis for the Netherlands at the microeconomic level and obtain qualitatively similar results.
} 
industries. Overall, the combined estimates of spillovers are rather high and for the sample as a whole comparable to the estimate of R\&D intensity. ${ }^{23}$ In addition, comparing the regression results in Table 5 with the ones in Table 3, we observe that an analysis like the one reported in Table 3 underestimates the effects of technology on skill upgrading for all three definitions of more-skilled workers. Taking into account knowledge spillovers generally reduces the coefficient on R\&D intensity but leads to a much larger impact of technology on skill upgrading via the channel of knowledge spillovers. $^{24}$

\section{Conclusions}

This paper has analysed to what extent changes in the employment shares of more skilled workers can be explained by technological change. Our findings are consistent with the previous literature on skill-biased technological change that there seems to be a positive and significant correlation between skill upgrading and technological change. However, our analysis has not only included surges in the creation and development of new technologies (R\&D) but also the spillovers from new technologies. By using knowledge spillovers, we are able to capture the usage of new technologies as well. It turns out that knowledge spillovers contribute a nonnegligible part to the story of skill upgrading. The coefficients on the knowledge spillovers, measured both domestically and internationally, are in most instances positively and significantly contributing to skill upgrading. The joint size of the effect is comparable to the impact of R\&D on skill upgrading.

Second, we used different definitions of more skilled workers. We used high-skilled workers, white-collar high-skilled workers and nonproduction workers. From a theoretical point of view, distinguishing between these three definitions is important because they consist of different workers. High-skilled workers are selected by the level of occupation they are working in; white-collar high-skilled are a subgroup of the highskilled workers; and nonproduction workers, most widely applied in international studies on skill-biased technological change so far, are defined as workers in white-collar occupations. However, the estimates show that, although the shares of the definitions of more skilled workers differ to some extent, the point estimates are different but not statistically significantly so.

Finally, we distinguished between high-tech and low-tech industries. This distinction leads to different estimates. We found regression results pointing at a larger role for spillovers in low-tech manufacturing industries compared to high-tech industries to explain skill upgrading. In high-tech industries, own R\&D efforts are more important in explaining skill upgrading.

\footnotetext{
23 We tested whether or not a constant returns to scale specification can be used to estimate this change. The results are that constant returns to scale can only be accepted for the low-tech sectors. In all other cases we have to reject this hypothesis.

24 Testing for differences in the dependent variables leads to the conclusion that we are not able to significantly distinguish between them.
} 


\section{Appendix A. Spillover matrix}

\begin{tabular}{|c|c|c|c|c|c|c|c|c|c|c|c|c|c|c|c|c|c|c|c|c|c|c|}
\hline & 1 & 2 & 3 & 4 & 5 & 6 & 7 & 8 & 9 & 10 & 11 & 12 & 13 & 14 & 15 & 16 & 17 & 18 & 19 & 20 & 21 & 22 \\
\hline 1 & 0.000 & 0.007 & 000 & 004 & .284 & 263 & 001 & 0.000 & 0.002 & 000 & .000 & 0.019 & 091 & 0.000 & 0.002 & 003 & 0.000 & 0.001 & 0.000 & 0.000 & .039 & 0.010 \\
\hline 2 & 0.006 & 0.000 & 0.002 & 0.026 & 0.085 & 0.005 & 0.001 & 0.016 & 0.018 & 0.002 & 0.091 & 0.042 & .249 & 0.003 & 0.012 & 0.013 & 0.000 & 0.006 & 0.002 & 0.004 & 0.050 & 0.083 \\
\hline 3 & 0.003 & 0.017 & 0.000 & 0.204 & 0.074 & 0.008 & 0.000 & 0.020 & 0.017 & 0.001 & 0.000 & 0.247 & 0.096 & 0.004 & 0.004 & 0.018 & 0.001 & 0.006 & 0.002 & 0.016 & 0.092 & 0.061 \\
\hline 4 & 0.003 & 0.088 & 0.003 & 0.000 & 0.105 & 0.022 & 0.003 & 0.006 & 0.011 & 0.008 & 0.003 & 0.034 & 0.163 & 0.041 & 0.006 & 0.024 & 0.001 & 0.004 & 0.001 & 0.001 & .105 & 0.087 \\
\hline 5 & 0.013 & 0.018 & 0.000 & 0.011 & 0.000 & 0.167 & 0.025 & 0.002 & 0.039 & 0.004 & 0.002 & 0.018 & 0.085 & 0.004 & 0.007 & 0.013 & 0.000 & 0.001 & 0.000 & 0.001 & 0.043 & 0.014 \\
\hline 6 & 0.025 & 0.002 & 0.000 & 0.003 & 0.261 & 0.000 & 0.006 & 0.000 & 0.001 & 0.000 & 0.000 & 0.003 & 0.031 & 0.000 & 0.000 & 0.001 & 0.000 & 0.000 & 0.000 & 0.000 & 0.023 & 0.002 \\
\hline 7 & 0.005 & 0.003 & 0.000 & 0.007 & 0.371 & 0.070 & 0.000 & 0.000 & 0.029 & 0.005 & 0.000 & 0.042 & 0.111 & 0.004 & 0.005 & 0.046 & 0.000 & 0.001 & 0.000 & 0.000 & 0.106 & 0.004 \\
\hline 8 & 0.006 & 0.126 & 0.025 & 0.016 & 0.046 & 0.005 & 0.005 & 0.000 & 0.012 & 0.002 & 0.001 & 0.119 & 0.142 & 0.007 & 0.007 & 0.156 & 0.000 & 0.093 & 0.001 & 0.023 & .144 & 0.029 \\
\hline 9 & 0.003 & 0.004 & 0.007 & 0.042 & 0.135 & 0.008 & 0.001 & 0.001 & 0.000 & 0.005 & 0.001 & 0.107 & 0.212 & 0.002 & 0.008 & 0.020 & 0.001 & 0.005 & 0.001 & 0.001 & 0.049 & 0.020 \\
\hline 10 & 0.000 & 0.003 & 0.000 & 0.002 & 0.035 & 0.002 & 0.001 & 0.000 & 0.024 & 0.000 & 0.187 & 0.095 & 0.123 & 0.001 & 0.001 & 0.030 & 0.000 & 0.007 & 0.000 & 0.000 & 0.021 & 0.004 \\
\hline 11 & 0.000 & 0.002 & 0.000 & 0.016 & 0.069 & 0.007 & 0.003 & 0.001 & 0.020 & 0.298 & 0.000 & 0.085 & 0.092 & 0.002 & 0.008 & 0.043 & 0.000 & 0.007 & 0.000 & 0.001 & 0.015 & 0.010 \\
\hline 12 & 0.004 & 0.003 & 0.016 & 0.034 & 0.027 & 0.004 & 0.002 & 0.004 & 0.038 & 0.012 & 0.009 & 0.000 & 0.187 & 0.004 & 0.016 & 0.052 & 0.002 & 0.026 & 0.002 & 0.004 & 0.051 & 0.024 \\
\hline 13 & 0.029 & 0.020 & 0.002 & 0.016 & 0.069 & 0.014 & 0.003 & 0.002 & 0.020 & 0.007 & 0.006 & 0.110 & 0.000 & 0.005 & 0.007 & 0.024 & 0.002 & 0.039 & 0.003 & 0.004 & 0.060 & 0.030 \\
\hline 14 & 0.000 & 0.001 & 0.001 & 0.006 & 0.006 & 0.001 & 0.000 & 0.000 & 0.001 & 0.000 & 0.000 & 0.008 & 0.012 & 0.000 & 0.075 & 0.027 & 0.000 & 0.004 & 0.000 & 0.002 & 0.075 & 0.019 \\
\hline 15 & 0.000 & 0.002 & 0.000 & 0.001 & 0.017 & 0.001 & 0.000 & 0.000 & 0.004 & 0.001 & 0.001 & 0.011 & 0.010 & 0.056 & 0.000 & 0.187 & 0.000 & 0.001 & 0.001 & 0.005 & 0.065 & 0.008 \\
\hline 16 & 0.001 & 0.002 & 0.001 & 0.005 & 0.008 & 0.000 & 0.000 & 0.001 & 0.009 & 0.002 & 0.007 & 0.038 & 0.029 & 0.020 & 0.355 & 0.000 & 0.000 & 0.012 & 0.001 & 0.006 & 0.059 & 0.005 \\
\hline 17 & 0.000 & 0.004 & 0.001 & 0.002 & 0.004 & 0.000 & 0.000 & 0.001 & 0.004 & 0.000 & 0.000 & 0.038 & 0.088 & 0.002 & 0.001 & 0.012 & 0.000 & 0.444 & 0.010 & 0.049 & 0.035 & 0.015 \\
\hline 18 & 0.001 & 0.005 & 0.005 & 0.057 & 0.019 & 0.001 & 0.000 & 0.044 & 0.039 & 0.002 & 0.001 & 0.085 & 0.194 & 0.003 & 0.007 & 0.027 & 0.003 & 0.000 & 0.004 & 0.080 & 0.033 & 0.023 \\
\hline 19 & 0.000 & 0.000 & 0.003 & 0.004 & 0.008 & 0.000 & 0.000 & 0.005 & 0.005 & 0.001 & 0.000 & 0.062 & 0.153 & 0.006 & 0.014 & 0.028 & 0.029 & 0.133 & 0.000 & 0.015 & 0.077 & 0.024 \\
\hline 20 & 0.000 & 0.001 & 0.002 & 0.003 & 0.002 & 0.000 & 0.000 & 0.001 & 0.003 & 0.001 & 0.000 & 0.044 & 0.061 & 0.003 & 0.005 & 0.065 & 0.004 & 0.479 & 0.003 & 0.000 & 0.041 & 0.007 \\
\hline 21 & 0.011 & 0.003 & 0.001 & 0.022 & 0.071 & 0.111 & 0.005 & 0.001 & 0.005 & 0.002 & 0.001 & 0.026 & 0.085 & 0.044 & 0.038 & 0.035 & 0.000 & 0.005 & 0.002 & 0.002 & 0.000 & 0.019 \\
\hline 22 & 0.009 & 0.076 & 0.003 & 0.034 & 0.026 & 0.002 & 0.001 & 0.004 & 0.009 & 0.001 & 0.001 & 0.041 & 0.121 & 0.189 & 0.042 & 0.031 & 0.003 & 0.008 & 0.001 & 0.006 & .110 & 0.000 \\
\hline
\end{tabular}




\section{Acknowledgements}

We appreciate the constructive comments and suggestions of Lawrence Katz, Stephen Machin, John Van Reenen, Luc Soete, Bart Verspagen, Thomas Ziesemer, and particularly those of two referees and the co-editor on an earlier version of this paper. Ter Weel also acknowledges financial support from the Netherlands Organization for Scientific Research (NWO). An earlier version of this paper appeared as MERIT Research Memorandum 2000-001, Maastricht University, under the title "Technology, knowledge spillovers, and changes in skill structure".

\section{References}

Acemoglu, D., 2002. Technical change, inequality, and the labor market. Journal of Economic Literature 40, $7-72$.

Adams, J.D., 1999. The structure of firm R\&D, the factor intensity of production and skill bias. Review of Economics and Statistics 81, 499-510.

Autor, D.H., Katz, L.F., Krueger, A.B., 1998. Computing inequality: have computers changed the labor market. Quarterly Journal of Economics 113, 1169-1213.

Bartel, A.P., Sicherman, N., 1999. Technological change and wages: an interindustry analysis. Journal of Political Economy 107, 285-325.

Berman, E., Machin, S., 2000. Skill-biased technology transfers: evidence of factor-biased technological change in developing countries, Working paper, Boston University.

Berman, E., Bound, J., Griliches, Z., 1994. Changes in the demand for skilled labor within U.S. manufacturing: evidence from the annual survey of manufactures. Quarterly Journal of Economics 109, 367-397.

Berman, E., Bound, J., Machin, S., 1998. Implications of skill-biased technological change: international evidence. Quarterly Journal of Economics 113, 1245-1279.

Betts, J.R., 1997. The skill bias of technological change in Canadian manufacturing industries. Review of Economics and Statistics 79, 146-150.

Borghans, L., ter Weel, B., 2001. The diffusion of computers and the distribution of wages. Working paper, Maastricht University.

Bound, J., Johnson, G.E., 1992. Changes in the structure of wages in the 1980s: an evaluation of alternative explanations. American Economic Review 82, 371-392.

Bruinshoofd, A., Hollanders, H., ter Weel, B., 2001. Knowledge spillovers and wage inequality: an empirical analysis of Dutch manufacturing. Labour 15, 641-661.

Chennells, L., Van Reenen, J., 1999. Has technology hurt less skilled workers? An econometric survey of the effects of technical change and the structure of pay and jobs. Working paper, Institute for Fiscal Studies.

Christensen, L.R., Jorgenson, D.W., Lau, L.J., 1973. Transcendental logarithmic production frontiers. Review of Economics and Statistics 55, 28-45.

Coe, D.T., Helpman, E., 1995. International R\&D spillovers. European Economic Review 45, 859-887.

Colecchia, A., Papaconstantinou, G., 1996. The evolution of skills in OECD countries and the role of technology. STI working paper 1996/8, OECD.

Doms, M., Dunne, T., Troske, K.R., 1997. Workers, wages, and technology. Quarterly Journal of Economics 112 , $253-290$.

Freeman, R.B., Katz, L.F., 1995. Differences and Changes in Wage Structures. University of Chicago Press, Chicago.

Goldin, C., Katz, L.F., 1998. The origins of technology-skill complementarity. Quarterly Journal of Economics $113,693-732$.

Gould, E.D., Moav, O., Weinberg, B.A., 2001. Precautionary demand for education, inequality, and technological progress. Journal of Economic Growth 6, 285-315.

Goux, D., Maurin, E., 2000. The decline in demand for unskilled labor: an empirical analysis method and its application to France. Review of Economics and Statistics 82, 596-607. 
Griliches, Z., 1979. Issues in assessing the contribution of research and development to productivity growth. Bell Journal of Economics 10, 92-116.

Griliches, Z., 1980. R\&D and productivity slowdown. American Economic Review 70, 343-348.

Griliches, Z., 1992. The search for R\&D spillovers. Scandinavian Journal of Economics 94, 29-47.

Hollanders, H., ter Weel, B., 2000. Technology, knowledge spillovers, and changes in skill structure. MERIT research memorandum 2000-001, Maastricht University.

Jaffe, A.B., 1986. Technological opportunity and spillovers of R\&D: evidence from firms' patents, profits, and market value. American Economic Review 76, 984-1001.

Juhn, C., Murphy, K.M., Pierce, B., 1993. Wage inequality and the rise in returns to skill. Journal of Political Economy 101, 410-442.

Katz, L.F., Murphy, K.M., 1992. Changes in relative wages, 1963-1987: supply and demand factors. Quarterly Journal of Economics 107, 33-78.

Keller, W., 1998. Are international R\&D spillovers trade-related? Analysing spillovers among randomly matched trade partners. European Economic Review 42, 1469-1481.

Kortum, S., Putnam, J., 1997. Assigning patents to industries: tests of the Yale technology concordance. Economic Systems Research 9, 161-175.

Krusell, P., Ohanian, L.E., Ríos-Rull, J.V., Violante, G.L., 2000. Capital-skill complementarity and inequality: a macroeconomic analysis. Econometrica 68, 1029-1053.

Machin, S., 1996. Changes in the relative demand for skills. In: Booth, A., Snower, D.J. (Eds.), Acquiring Skills. Cambridge Univ. Press, Cambridge, pp. 129-146.

Machin, S., Van Reenen, J., 1998. Technology and changes in skill structure: evidence from seven OECD countries. Quarterly Journal of Economics 113, 1215-1244.

Murphy, K.M., Welch, F., 1992. The structure of wages. Quarterly Journal of Economics 107, 285-326.

OECD, 1998a. Bilateral Trade Database (BTD), Paris.

OECD, 1998b. Structural Analysis (STAN) Database, Paris.

OECD, 1999. Analytical Business Enterprise Research and Development (ANBERD) Database, Paris.

Putnam, J., Evenson, R., 1994. Inter-sectoral technology flows: estimates from a patent concordance with an application to Italy. Working paper, Yale University.

Romer, P.M., 1990. Endogenous technological change. Journal of Political Economy 98, S71-S102.

Scherer, F.M., 1982. Inter-industry technology flows and productivity growth. Review of Economics and Statistics 64, 627-634.

Soete, L., ter Weel, B., 1999. Innovation, knowledge creation and technology policy: the case of the Netherlands. De Economist 147, 293-310.

Verspagen, B., 1997a. Estimating international technology spillovers using technology flow matrices. Weltwirtschaftliches Archiv 133, 226-248.

Verspagen, B., 1997b. Measuring intersectoral technology spillovers: estimates from the European and US patent office databases. Economic Systems Research 9, 47-65. 